\title{
Energy Market Regulations and Productivity: An Examination on OECD Countries between the Years of 1975-2007
}

Işıl Şirin SELÇUK, Department of Economics, Faculty of Economics and Administrative Sciences, Abant Izzet

Baysal University, Turkey; e-mail: isilselcuk@ibu.edu.tr

Altuğ Murat KÖKTAŞ, Department of Public Finance, Faculty of Economics and Administrative Sciences, Nigde University, Turkey; e-mail: altugmuratkoktas@nigde.edu.tr

\section{Enerji Piyasası Düzenlemeleri ve Üretkenlik: 1975-2007 Yılları için OECD Ülkeleri Üzerine Bir İnceleme}

\begin{abstract}
Regulations in energy markets that began in a number of countries in 1980s has become more widespread in many countries especially in 2000s. In this context, the fact that how the sectorial regulations affect the economy has become an important point in the name of policy implementers. Within the scope of this study, the effect of anti-competitive regulations in energy markets of OECD countries between the years of 1975 - 2007 on total factor productivity was examined. It is aimed to evaluate effects of sectorial anti-competitive regulation by the use of regulation impact indicator that has been taken from the data base of OECD. In econometric estimations, which were performed by using unbalanced panel data, Cobb-Douglas type of production function that includes energy was characterized and total factor productivity was calculated as residuals of production function in this direction. In consequence of the analysis, it is stated that in case when the regulations in energy market are anti-competitive, they affect total factor productivity in a negative direction.
\end{abstract}

Keywords

Energy Policy, Regulation, Total Factor Productivity, Production Function.

JEL Classification Codes : D24, Q43, Q48, L51.

\section{Öz}

1980'li yıllarda birkaç ülkede başlayan enerji piyasalarındaki serbestleşme, özellikle 2000'li yıllara gelindiğinde pek çok ülkede yaygınlaşmıştır. Bu bağlamda politika uygulayıcılar için sektörel düzenlemelerin ekonomiyi nasıl etkilediği önemli bir nokta olmaktadır. Çalışmada 1975-2007 yılları arasında OECD ülkeleri enerji piyasalarındaki rekabet karşıtı düzenlemelerin toplam faktör üretkenliği üzerindeki etkisi incelenmiştir. OECD'nin veri tabanından alınan düzenleme etkisi göstergesi kullanılarak sektörel rekabet karşıtı düzenlemelerin etkilerinin göz önünde bulundurulması amaçlanmıştır. Dengesiz panel veri kullanılarak yapılan ekonometrik tahminlerde enerjiyi içeren Cobb-Douglas tipi üretim fonksiyonu tanımlanmış ve toplam faktör üretkenliği bu doğrultuda üretim fonksiyonunun artıkları olarak hesaplanmıştır. Analiz sonucunda enerji piyasasında yapılan düzenlemelerin, rekabeti engelleyici olması durumunda toplam faktör üretkenliğini negatif yönde etkilediği belirlenmiştir. 
Selçuk, I.Ş. \& A.M. Köktaş (2016), "Energy Market Regulations and Productivity: An Examination on OECD Countries between the Years of 1975-2007", Sosyoekonomi, Vol. 24(27), 243-261.

Anahtar Sözcükler
: $\quad$ Enerji Politikası, Düzenleme, Toplam Faktör Verimliliği, Üretim Fonksiyonu.

\section{Introduction}

Along with the process of globalization, technological progress, modernization, increased population and global expansion; the energy sector has come to a very important position in terms of both supply and demand to which all the eyes turned. Therefore, today energy resources in many areas constitute the raw materials of many products and are used to meet the global energy needs. However, the variety and use of energy sources vary over the years. Traditionally used fuels such as coal and wood are still used, yet the energy sources such as natural gas, renewable energy, and nuclear energy are also used.

The traditional structure of the production, spillover and distribution of energy, especially of electrical energy, began to be criticized from the beginning of the 1980s in the world and in order for the change of this nature, the steps have been taken primarily in the. The existing traditional and monopolistic structure causes negativities in terms of effective use of resources, competition, efficiency and quality of services; and that is considered as the main axis of the criticism.

There are many impacts of the energy market reform processes on the countries especially in terms of economic, social and environmental dimensions. Therefore, it is important to evaluate the causes and consequences of the reforms and understand this changing structure of the energy market. In this way, it will be possible to identify sustainable, environmentally friendly, effective policies that reduce dependence. Similarly, the reforms on the market have direct and indirect effects on the main players of the market as well as the industry and the household. It is important to know the impact of the reforms on these key players in order to analyze the implications of these on the economy in the short and long term.

In this article, it is aimed to examine the impact caused in the economy by anticompetitive arrangements made in the energy market for the OECD member countries. In this context, the concept of total factor productivity will be used. In the following section, the transformation of the energy market is described; then the arrangement impact indicators and the energy use in production function that form the basis of the analysis. In the subsequent parts, the focus is on empirical analysis and the estimation strategies are mentioned with respectively the total factor productivity calculation methods in the data sets, models and literature. Finally the model is estimated and the article is finalized by interpreting the results. 
Selçuk, I.Ş. \& A.M. Köktaş (2016), "Energy Market Regulations and Productivity: An Examination on OECD Countries between the Years of 1975-2007", Sosyoekonomi, Vol. 24(27), 243-261.

\section{The Liberalization of the Energy Market and the Regulations Made in the Markets}

Comprehensive programs such as reconstruction, privatization of liberalization in different sectors such as telecommunications, energy, postal services and railways in many different countries such as the US, Argentina, Britain, France, Mexico, Norway, Russia, and New Zealand including Turkey in the last 20-25 years all over the world entered into force. However, this part will focus in particular on the change of the countries in terms of the energy market.

The liberalization movements of the energy market is often defined as the establishment of independent energy sector regulators along with the steps towards launching and increasing competition in the market, yet sometimes only the privatizations are referred.

The changes in the energy market in the world basically began in the early 1980s. The main reason for this is the cost problems created by the oil crisis as well as the declining growth rate of electricity demand and the increased electricity prices in real terms at the end of the 1970s. When the discontent of the sector performance and the impression that the observed problem has become chronic was combined with the tendency to give more weight to market which put its mark generally on those years, the new industry structure quests have come up on the agenda which included more private actors in the electricity sector and thus aimed at the increase of economic efficiency (Zenginobuz, 2000: 104).

Prior to 1980, public ownership was preferred in the provision of energy services in many countries, while the reforms including privatization, liberalization, and the restructuring of the energy market in the developing and developed countries started to be discussed and considered as a solution along with the national differences.

In his study on the liberalization process of the energy markets, Politt (2012) stated that the liberalization of the gas supply in the oil and exploration-production stage is related to the full or partial privatization of the state-owned companies. He also stated that the liberalization of the gas supply at the refining, processing and distribution phase can be associated with structural reforms in order to make the wholesale and retail sales competitive in the privatizations and national industries. The liberalization of the coal market is in line with the development of the electricity and gas markets in the country.

Finally, if we are to examine the arrangements of the energy market in the OECD area, we see that the OECD indicators suggest that quantitative market-oriented reforms got more common in the last twenty years. The following graphs were prepared using the OECD regulation indicators data (Conway et al., 2006). The regulation indicator grades the arrangements of the countries outside the manufacturing industry between 0 and 6; and 0 represents the least restrictive condition, while 6 represents the most restrictive condition. It is possible to access these grades since 1975 for each country. 
When the graphs are examined, several countries such as the United Kingdom, Norway and Canada have been observed in between 1970 and 1980 to begin the reforms. Especially after the 1990s, it is possible to say that the regulations on the electricity and gas markets for all countries are aimed at increasing liberalization of the markets.

\section{Graph: 1
Country Scores of 1975}

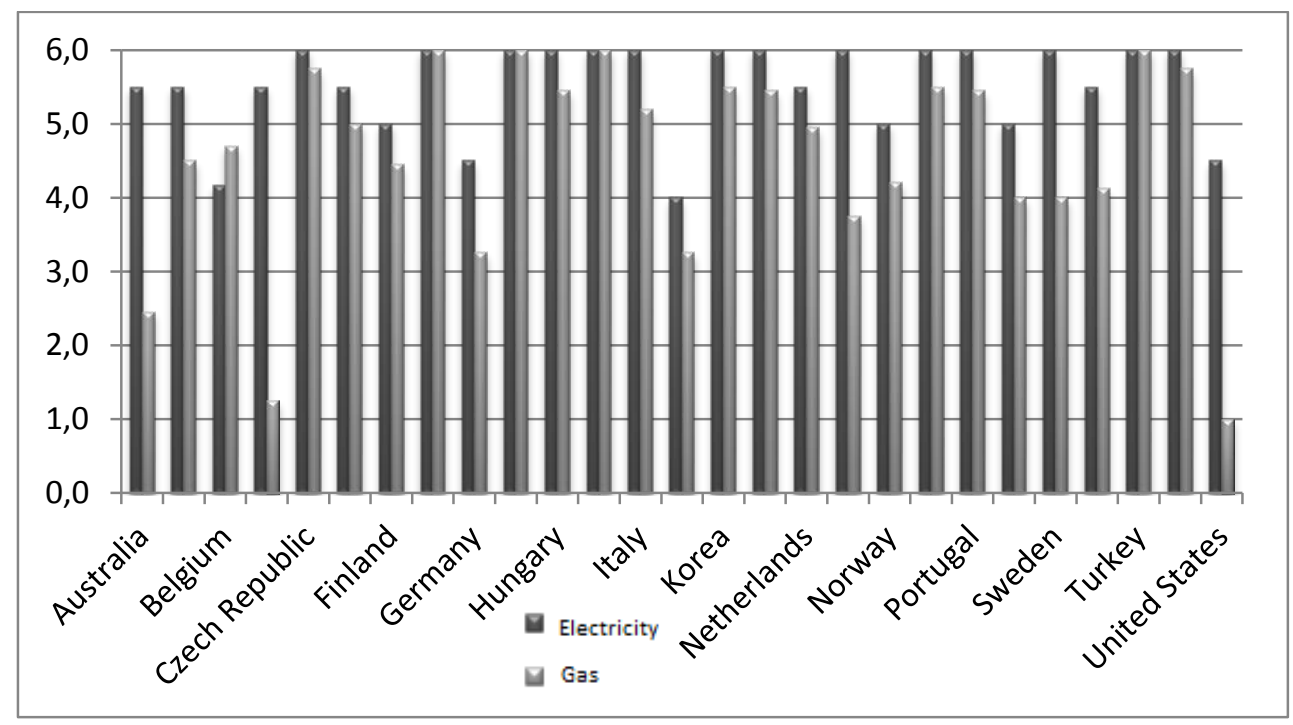


Graph: 2

Country Scores of 2007

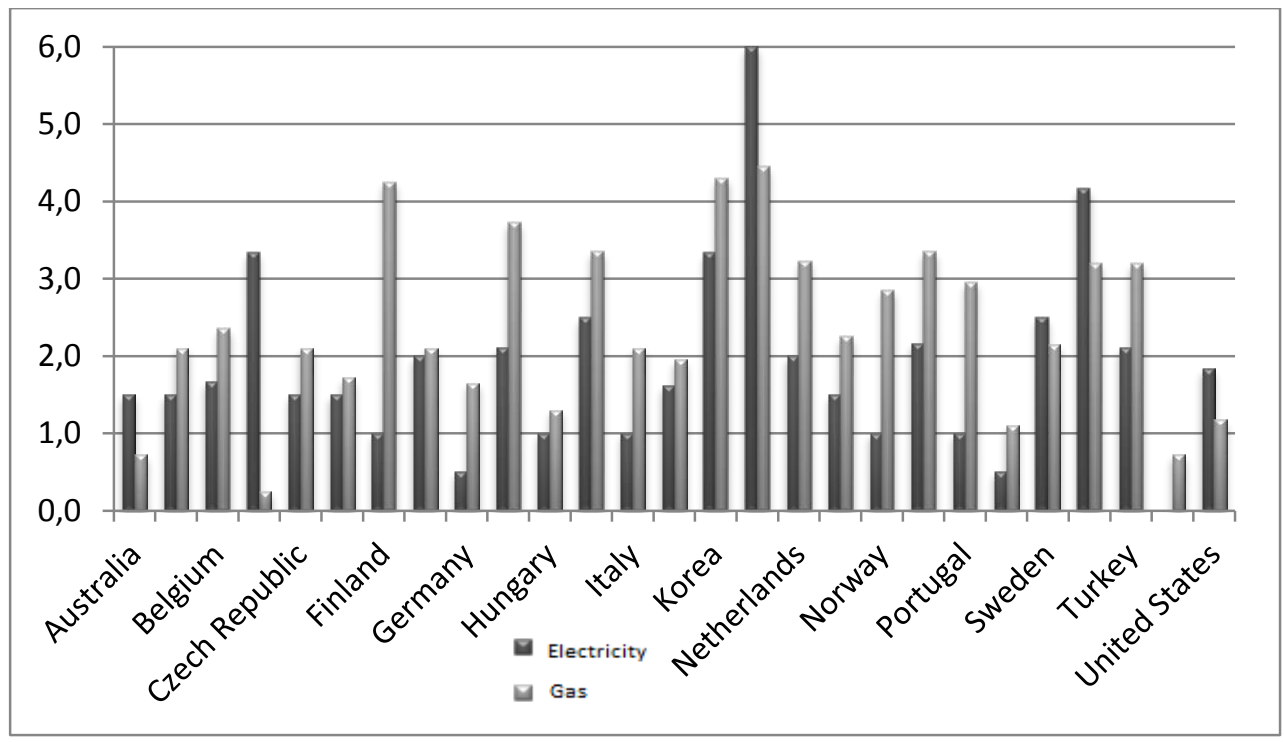

If it is necessary to further clarify this issue, we can say that the average grades of the electricity market in the 27 member countries of OECD are respectively 5.5, 5.1 and 1.9 for 1970, 1991 and 2007. This is an indication that the liberalization of the electricity market has accelerated in the 1990s. A similar situation also applies to natural gas. The natural gas market average of 27 member countries of the OECD are respectively 4.6, 4.4 and 2.4 for 1970, 1991 and 2007. Another conclusion drawn from the grading is that the natural gas market was much more liberalized than the electricity market in the 1970s, while the liberalization of the electricity market was more in the 2000s.

When this graph is examined for Turkey, it is noted that Turkey follows a similar trend as the other OECD member countries. In this context, while there was a stricter electricity and gas market in the 1970s, the liberalization accelerated in both markets in the 2000s. While the electricity market grade in 1975 was 6 which showed the strictest state, it fell to 2.7 in 2007. A similar transformation occurred in the natural gas market and the grade 6 of the 1975 fell to 3.2 in 2007 just as the electricity market. Another important point to note here is that Turkey's electricity market has more free market conditions than the natural gas market in 2007. 


\section{Regulation Impact Indicators}

The regulation impact indicators which form the basis of the analysis in this study are the industrial indicators measuring the chain/indirect impacts of the non-manufacturing sector regulations on all sectors of the economy as defined by the OECD. The main pillar of this indicator is that the regulations applied on a certain sector affect the organizational structure and the costs of other sectors which use the product in this sector as inputs.

While explaining the regulatory impact factor, Conway et al. (2006) stated that the anti-competitive regulation indicators in the non-manufacturing sectors are used in calculating the indirect effects of the regulatory conditions on the sector level not only on a time series, but also on the horizontal section. It has been found out that the anti-competitive regulation indicators in the non-manufacturing sectors do not have a direct impact on the market conditions in these sectors, but also have less visible impacts on the cost structures encountered by the companies that use outputs from the non- manufacturing sectors as the intermediate input in the production processes. In other words, the impact of the market regulations that restrict competition in the non-manufacturing sectors is not limited to that sector and affects the sectors where it is used as intermediate inputs.

Thus, the arrangements in the non-manufacturing sectors will be distributed in the economy through other channels such as the impacts on the prices of investment goods and wages. While calculating the regulatory impact factor, the input coefficients are used for each country with the help of input - output tables. In this way it is possible to measure which intermediate input is used as the final output. Therefore, the regulatory impact indicator is a measure of to what extent each sector of the economy is exposed to anti-competitive arrangements in the non-manufacturing sectors.

The formula used to calculate the regulatory impact indicators is as follows: $\mathrm{RIF}_{\mathrm{kt}}=\sum_{\mathrm{j}} \mathrm{R}_{\mathrm{jt}} \cdot \mathrm{W}_{\mathrm{jk}}$ where the variable $\mathrm{R}_{\mathrm{jt}}$ is an indicator of anti-competitive regulation in non-manufacturing sector $\mathrm{j}$ at time $t$ and the weight $\mathrm{W}_{\mathrm{jk}}$ is the total input requirement of sector $\mathrm{k}$ for intermediate inputs from non-manufacturing sector $\mathrm{j}$.

The total input coefficients in the formula above are used to measure the importance of the regulated industry which is the intermediate input supplier for another industry. These indicators are calculated for 29 OECD countries including the 1975-2007 period.

If the regulatory impact indicator value becomes high, it can be said that there are strong regulatory constraints. This means low competition. On the contrary, if it gets a low value, it indicates the high level of the competition.

Conway et al. (2006) used the regulatory impact indicators while studying the impact of the commodity market regulations on productivity shocks. For this reason, the anti-competitive variable including the above-mentioned non-manufacturing sectors 
(airlines, railways, road transport for transport, gas and electricity for energy, postal and telecom for communication) is used as a proxy for the regulations that apply to the entire economy. In this model, it is presumed that the shocks on the labor productivity of leader countries or sectors might have a direct impact on the labor productivity growth in the following countries. The model based on the productivity of labor estimated both the aggregate and sector levels. In the model, while the growth in labor productivity per worker is taken as the dependent variable, the independent variables are the variability in the productivity of the technology leaders, the difference at the productivity levels, goods market regulations, the interaction of the regulation and productivity deficit, production gap, human capital, information and communication technology investments, the country fixed effects and the country time trends. The empirical results showed that the restrictive property market regulations slow down the adjustment process and the impact of the anti-competitive arrangements were found to be negative and significant. The harmful effects of anticompetitive arrangements among all countries included in the study were greater in sectors that use information and communication technologies intensively.

Similarly, while examining the relationship between competition policy and productivity growth, Arnold et al. (2008) used the regulatory impact indicator variable. The purpose of this study is to provide new evidence about the arrangements and activities relationship of the resource allocation between firms. According to this, improper adjustments can affect productivity performance. According to the analysis using the error correcting model results with the basic properties of the multifactor productivity equation supported by policy, the resources are distributed less efficiently in the industries where the anti-competitive regulations (and particularly information and communication technologies) are more.

While examining the impact of market regulation on the competition degree based on flexibility of profitability and average profitability, Braila (2010) used this indicator. Since the indicator regulatory measures on the market competition showed its impact late in this study for the Belgian economy for the years 1997-2004, they are used as delayed for two years. The study concluded that the markets are more independent, therefore there is an increase in competition when the regulations in the economy are facilitated.

De Serres et al. (2006) examined the impacts of the regulations on the financial systems for the OECD countries using this indicator. In this sense, he analyzes whether the regulations in the banking system facilitated the competitiveness and are favorable for the development of the securities market, and whether they have a positive effect on the productivity, sector output, growth, and productivity growth and penetration rate of the companies into the market. The results obtained using panel regression techniques show that the financial system regulations have a statistically significant effect on the output and productivity growth as well as on company penetration.

In another study on the effects of the regulations made using panel data (Arnold et al, 2011) the relationship of firm-level productivity estimation and anti-competitive 
regulations were examined. In the analysis, the results confirmed that the competitiveness level affects the growth of total factor productivity. When the regulations on the product markets suppress the competition, it is determined that the productivity performance of the company reduces.

\section{Energy in the Production Function}

Energy is mostly neglected as a production factor in the traditional economic theory. The main basis of this is that energy has fewer shares in the total factor costs compared to labor and capital. However, energy is a basic need today and it is necessary for the production. Therefore, as the input, energy affects production and therefore the overall economics. Especially two major oil crises of the 1970s showed marked that energy might have big economic impacts; thus, all the energy production functions that included energy began to be formulated since the mid-1970s.

In the article on a production function that emphasizes energy for Austria, Tintner et al. (1977) used the Cobb-Douglas production function. When the Austria data are analyzed, optimum results are obtained when only the technical progress is considered with the constant returns to scale. The flexibility of energy production is obtained around $30 \%$.

Kümmel et al. (1985) stated that energy is a basic production factor just as capital and labor and presented the LINEX, the linear exponential production function as a function based on economic concerns as well as physics and technology. LINEX function has a linear dependency on energy, while it is exponentially dependent on labor capital ratio and energy capital ratio.

Lindenberger and Kümmel (2002) tried to integrate the economy with thermodynamics in their study, and stated that the production function is related to the capital, labor, energy, and technological parameters. Furthermore, they stated that the majority of the residues in the neo-classical growth model would disappear when dealt with in an appropriate manner as a factor of production (2002:102). In this context, PRISE which is an optimization model (Price Induced Sectoral Evolution) has been proposed. Model is designed for analyzing changes in inputs, outputs and profits in the different labor and energy intensive sectors of economy in response to the changing factor prices.

Lindenberger (2003) has expanded the LINEX production function to service sector production function. While expanding, he has obtained energy-dependent production functions by specifying the technological boundary conditions of production flexibility.

While examining the economic growth of Germany, Japan and the US, Kummel (2007) used LINEX production function which includes energy. As a result, when the share of production in the total factor cost of the average production flexibility is compared for 
those countries with a high level of industrialization, $70 \%$ for labor, $25 \%$ for capital and $5 \%$ for energy is observed.

Aside from the above-mentioned production functions, it is possible to often encounter production function with fixed nested substitution flexibility in the computable general equilibrium models which include energy / environment. As a result of the widespread use of nested CES production functions in the studies including capital, labor, energy and material, these functions are also named as KLEM production functions (Chang, 1994; Grepperud and Rasmussen, 2004; van der Werf, 2008). In the study in which where the energy should enter the production function is discussed, Lecca et al. (2011) stated that the most important feature of nested CES production functions is that they include a production function having the same elasticity of substitution in each slot regardless of the factor proportions and scale. Using such a hierarchical production function provides potential differentiation of substitution flexibility among the inputs in different nests. However, it should also be noted that the substitutability/ complementary relationship between the other factors of production (especially capital) and energy is a highly controversial subject in the literature (Sorrel, 2008; Thompson, 2006).

Even though many studies uses the nested CES function on this subject in some studies less restrictive functional forms are used. Thompson (2006) used Cobb-Douglas, log linear function, translog production function and cost functions. In his study, it is stated that simpler functional forms can be used for production estimates while production function is expanded with natural resources, energy, labor and capital inputs.

In addition to the above-mentioned energy is included in the production function in the studies examining energy and economic growth and the analyses are usually performed in this manner.

From this part on, the impact of the energy market regulations on the economy is analyzed. Therefore, a production function incorporating energy will be described in the study and the analysis and estimation methods are discussed and empirical analysis is made.

\section{Dataset}

The analysis included the real gross domestic product, real gross fixed capital stock, labor, energy use and impact indicators data were used from 28 OECD member countries for the period 1975-2007. The data set comprises of 806 observations and is an unbalanced panel data set. Further details of the data set are given in the Table 1 . 
Table: 1

Sample Properties

\begin{tabular}{|l|c|c|c|}
\hline Country & Observation & Share $(\%)$ & Coverage \\
\hline Australia & 33 & 4,09 & $1975-2007$ \\
\hline Austria & 33 & 4,09 & $1975-2007$ \\
\hline Belgium & 33 & 4,09 & $1975-2007$ \\
\hline Canada & 33 & 4,09 & $1975-2007$ \\
\hline Czech Republic & 18 & 2,23 & $1990-2007$ \\
\hline Denmark & 33 & 4,09 & $1975-2007$ \\
\hline Finland & 33 & 4,09 & $1975-2007$ \\
\hline France & 33 & 4,09 & $1975-2007$ \\
\hline Germany & 33 & 4,09 & $1975-2007$ \\
\hline Greece & 33 & 4,09 & $1975-2007$ \\
\hline Hungary & 28 & 3,47 & $1980-2007$ \\
\hline Ireland & 33 & 4,09 & $1975-2007$ \\
\hline Italy & 33 & 4,09 & $1975-2007$ \\
\hline Japan & 33 & 4,09 & $1975-2007$ \\
\hline Korea & 10 & 1,24 & $1998-2007$ \\
\hline Mexico & 10 & 1,24 & $1998-2007$ \\
\hline New Zealand & 33 & 4,09 & $1975-2007$ \\
\hline Norway & 33 & 4,09 & $1975-2007$ \\
\hline Poland & 19 & 2,36 & $1975-2007$ \\
\hline Portugal & 33 & 4,09 & $1975-2007$ \\
\hline Slovakia & 18 & 2,23 & $1975-2007$ \\
\hline Spain & 33 & 4,09 & $1975-2007$ \\
\hline Sweden & 33 & 4,09 & $1975-2007$ \\
\hline Switzerland & 33 & 4,09 & $1975-2007$ \\
\hline The Netherlands & 33 & 4,09 & $1975-2007$ \\
\hline Turkey & 10 & 1,24 & $1998-2007$ \\
\hline United Kingdom & 33 & 4,09 & $1975-2007$ \\
\hline United States of America & 33 & 4,09 & $1975-2007$ \\
\hline Total & 806 & 100 & \\
\hline & & & \\
\hline
\end{tabular}

Representing the capital accumulation Penn World Tables 8.0 capital stock data were used and these data are taken from the database of the Groningen Growth and Development Centre (Feenstra \& Inklaar \& Timmer, 2013). Gross fixed capital stock was calculated using the perpetual inventory method in constant 2005 national prices (2005 million US dollars). In addition to capital stock data, Penn World Tables are also used for the labor input.

For the output of the production function, real gross domestic product with constant 2005 national prices (million 2005 US dollars) is used, and like in labor and capital stock data Penn World Tables are used and data are taken from the database of Groningen Growth and Development Centre. Energy use data (kilotons of oil equivalent) is from the World Development Indicators database which is the data base of the World Bank. The regulation impact factor data is taken from the OECD database and is described in detail in previous chapters. The descriptive statistics of all variables are shown in Table 2. 
Table: 2

Descriptive Statistics

\begin{tabular}{|l|c|c|c|c|c|}
\hline Level & Observation & Mean & Std. Deviation & Min. & Max. \\
\hline Regulation Impact & 806 & 0,4384384 & 0,1659781 & 0,0738333 & 1 \\
\hline Energy & 806 & 177726 & 393667,6 & 6647,006 & 2337014 \\
\hline Real GDP & 806 & 959243,6 & 1806084 & 41823,63 & $1,31 \mathrm{E}+07$ \\
\hline Capital & 806 & 2965748 & 5749649 & 54400,41 & $3,94 \mathrm{E}+07$ \\
\hline Labor & 806 & 16,76435 & 26,03842 & 1,080892 & 147,8036 \\
\hline Logarithms & & & & & \\
\hline Ln Real GDP & 806 & 1.287 .152 & 1.258 .436 & 1.064 .122 & 1.639 .151 \\
\hline Ln Regulation Impact & 806 & $-0,9080582$ & 0,4327386 & $-2,605945$ & 0 \\
\hline Ln Energy & 806 & 11,06182 & 1,298834 & 8,801922 & 14,66438 \\
\hline Ln Capital & 806 & 13,89431 & 1,348818 & 10,90413 & 17,48897 \\
\hline Ln Labor & 806 & 2,045289 & 1,185984 & 0,077787 & 4,995885 \\
\hline Growth Rates & & & & & \\
\hline$\Delta$ Ln Real GDP & 778 & 0,0267011 & 0,024598 & $-0,1571321$ & 0,108815 \\
\hline$\Delta$ Ln Capital & 778 & 0,0328523 & 0,0196338 & 0,003027 & 0,334459 \\
\hline$\Delta$ Ln Labor & 778 & 0,0080778 & 0,0189823 & $-0,124651$ & 0,078592 \\
\hline$\Delta$ Ln Regulation Impact & 778 & $-0,0299719$ & 0,064284 & $-0,6998642$ & 0,036628 \\
\hline$\Delta$ Ln Energy & 778 & 0,0142396 & 0,0368216 & $-0,1823215$ & 0,19123 \\
\hline
\end{tabular}

\section{Model}

The production function to be estimated involves three factors, namely labor, capital and energy:

$$
\mathrm{Y}=\mathrm{F}(\mathrm{K}, \mathrm{L}, \mathrm{E})
$$

Here F (.) is assumed as the Cobb-Douglas production function, and energy input is also used along with the standard inputs. The spillover literature is used in measuring the impact of regulatory impacts on the economy at the estimation of production function and afterwards. The most common approach in the standard spillover literature is to estimate the total factor productivity by estimating the production function with the help of factor inputs. The resultant total factor productivity estimations also subjected to a certain information spillover criteria regression.

From this point of view, the equation of the production function of Griliches (1979) is as follows:

$$
Y=A L^{\alpha} K^{\beta} E^{\gamma} e^{\lambda t+u}
$$

In this model constant, time index which captures a common linear trend is $t$, stochastic error terms are $\lambda$ and e. Parameters to be estimated are $\lambda$ and e. If the logarithms are taken when estimating the model, the equation becomes as follows where i denotes crosssectional units and $t$ denotes cross-sectional units: 


$$
y_{i t}=\alpha_{i} l_{i t}+\beta_{i} k_{i t}+\gamma_{i} e_{i t}+\lambda_{t}+u_{i t} \text { ve } \alpha_{i}=\alpha, \beta_{i}=\beta, \gamma_{i}=\gamma, \forall_{i}
$$

Residues obtained from the estimation of the production function are taken as an indication of the productivity in a compatible manner with the literature. Thus, the part unexplainable with factors of production, in other words, the second part of the analysis on how the total factor productivity is affected by regulations impact indicators was performed.

\section{Estimation Strategy and Results}

First of all, cross section and time series properties of the data were investigated before estimating the model. For this purpose, first generation unit root test (Maddala and $\mathrm{Wu}, 1999$ ) and second generation unit root test (Pesaran, 2007) was applied to all variables. In addition to unit root tests, cross sectional dependency test (Pesaran, 2004) was applied to all variables. The detailed results were presented in the appendix section of this study. The main reason why the unit root tests were performed carefully was that disregarding of unit root problem in the analysis of panel data causes the spurious regression.

It was revealed as a result of the root tests of the panel unit that the variables had unit roots on level, but after taking their first differences, they became stationary. Besides, it was revealed according to the results of cross sectional dependency tests that all variables were dependent both on level and after first differences was taken.

The issue that became important after this stage is to estimate the production function correctly. Since the variables show cross sectional dependency, it should be examined in the result of analysis if the residuals are dependent on cross sections as well. When the cross sectional dependency test of the residuals were performed, if they were determined as cross sectional dependent, this situation might cause the estimations likely to be inconsistent and biased. This means that the statistically significant spillover variable reflects the data dependencies, originated from other common factors in the countries and sectors included in the sample, rather than representing the real spillovers (Eberhardt \& Helmers \& Strauss, 2013).

Therefore, after this stage, within the scope of the research question, the empirical practice is based on the study of Eberhardt, Helmers and Strauss (2013) and is carried out using different estimators. Thus, it was intended to make the most accurate estimation of production function.

It is possible to summarize the different approaches used in the study with the table given below: 


\section{Table: 3}

\section{Empirical Approach ${ }^{1}$}

\begin{tabular}{llll} 
& & \multicolumn{2}{l}{ Impact of Unobservables } \\
& & Common & Heterogeneous \\
Technology Parameters & Common & POLS, 2FE, FD & CCEP \\
& Heterogeneous & CDMG & MG, CMG
\end{tabular}

Eberhardt, Helmers, and Strauss, 2013.

Each estimator in the table includes different assumptions about the basic data generating process. First of all the models, of which technology parameters are mutual, and then the models with heterogeneous technology parameters were estimated and afterwards the results were evaluated. The cross-sectional dependency for the residuals of all estimated models and constant returns to scale were tested, the order of integration was investigated and the most appropriate model was intended to be selected.

Common technology parameter model assumes a common technology for factor inputs. This assumption was modified in the models, in which heterogeneous technology parameters were assumed. For the estimators on the left side of the table dummy variable representing the year was augmented. As well as cross-section demeaned mean group estimator has an assumption of common impact of unobservable factors, it is heterogeneous in terms of technology parameters. The right side of the table allows the unobservable factors to vary from country to country.

All of the mean group estimators, used in the estimations follow the same methodology. According to this methodology, the first stage is the estimation of the least squares regression in respect of the countries and the regions. The second stage is to calculate the arithmetic averages of the estimated coefficients of the groups in themselves. Mean group estimator models and estimates the unobservable effects through a linear trend. Common correlated mean group estimator uses the regression equations, which have been augmented with time vector belonging to the each cross section unit. The estimated equation with this estimator includes the cross section averages of the dependent and independent variables as well. Thus, the consistent estimations of the parameters with respect to the observed variables could be obtained.

The statistically standard pooled estimations of the production function are given in Table 4. The pooled common correlated effects estimator was estimated both with its standard version and year dummy variable. Wald test was applied to measure the assumption

1 POLS: Pooled Ordinary Least Squares; 2FE: Two-way fixed effects FD: First Difference Least Squares; MG: Mean Group; CCEP: Pooled common correlated effects; CDMG: Cross section demeaned mean group; CMG: Common correlated mean group estimator. 
of constant returns to scale for each model; the unit root tests as well as the cross sectional dependency test were performed to the residuals.

Table: 4

Production Functions (Static, Common Technology Parameters)

\begin{tabular}{|c|c|c|c|c|c|}
\hline Estimator & FD & POLS & CCEP & CCEP & $2 \mathrm{FE}$ \\
\hline Ln_capital & $\begin{array}{l}.043 \\
(0.35)\end{array}$ & $\begin{array}{c}0.562 \\
(28.56)^{* *}\end{array}$ & $\begin{array}{c}.348 \\
(3.22)^{* *}\end{array}$ & $\begin{array}{c}.114 \\
(0.87)^{* *}\end{array}$ & $\begin{array}{c}.448 \\
(9.47)^{* *}\end{array}$ \\
\hline Ln_labour & $\begin{array}{l}.553 \\
(7.26)^{* *}\end{array}$ & $\begin{array}{c}.212 \\
(9.20)^{* *}\end{array}$ & $\begin{array}{c}.543 \\
(4.47)^{* *}\end{array}$ & $\begin{array}{c}.636 \\
(4.66)^{* *}\end{array}$ & $\begin{array}{c}.470 \\
(11.55)^{* *}\end{array}$ \\
\hline Ln_energy & $\begin{array}{l}.172 \\
(5.36)^{* *}\end{array}$ & $\begin{array}{c}.191 \\
(14.75)^{* *}\end{array}$ & $\begin{array}{c}.294 \\
(5.21)^{* *}\end{array}$ & $\begin{array}{c}.193 \\
(3.04)^{* *}\end{array}$ & $\begin{array}{c}-0.022 \\
(0.78) \\
\end{array}$ \\
\hline Constant & $\begin{array}{l}.024 \\
(3.71)^{* * *}\end{array}$ & $\begin{array}{c}2.510 \\
(11.85)^{* *}\end{array}$ & $\begin{array}{l}-.347 \\
(2.05)\end{array}$ & $\begin{array}{c}7.123 \\
(4.68)^{* * *}\end{array}$ & $\begin{array}{c}5.82 \\
(11.37)^{* *}\end{array}$ \\
\hline$N$ & 778 & 806 & 806 & 806 & 806 \\
\hline Year Dummies & Included & Included & Not Included & Included & Implicit \\
\hline $\begin{array}{c}\text { Constant Returns to Scale } \\
(p \text {-value })\end{array}$ & 0.012 & 0.00 & .023 & 603 & 0.00 \\
\hline $\begin{array}{c}\text { Cross Sectional Dependency } \\
(p \text {-value })\end{array}$ & 0.00 & 0.00 & 0.00 & 0.00 & 0.00 \\
\hline Order of Integration & $\mathrm{I}(0)$ & $\mathrm{I}(1) \sim \mathrm{I}(0)$ & $\mathrm{I}(1)$ & $\mathrm{I}(1)$ & I (1) \\
\hline
\end{tabular}

The estimation results of the models with heterogeneous technology parameters are given in Table 5. All models were estimated as including, or not including trend.

Table: 5

\section{Heterogeneous Production Functions (Static)}

\begin{tabular}{|c|c|c|c|c|c|c|}
\hline Estimator & MG & MG & $\overline{\mathrm{CDMG}}$ & CDMG & CMG & CMG \\
\hline Ln_capital & $\begin{array}{c}.205 \\
(4.31)^{* *}\end{array}$ & $\begin{array}{c}.277 \\
(4.17)^{* *}\end{array}$ & $\begin{array}{l}0.113 \\
(1.87)\end{array}$ & $\begin{array}{l}0.063 \\
(0.54)\end{array}$ & $\begin{array}{c}.129 \\
(2.94)^{* *}\end{array}$ & $\begin{array}{c}.125 \\
(2.06)^{*}\end{array}$ \\
\hline Ln_labour & $\begin{array}{r}.099 \\
(0.77)\end{array}$ & $\begin{array}{c}.558 \\
(9.20)^{* *}\end{array}$ & $\begin{array}{c}0.487 \\
(4.59)^{* *}\end{array}$ & $\begin{array}{c}0.436 \\
(3.99)^{* *}\end{array}$ & $\begin{array}{c}.123 \\
(1.16)\end{array}$ & $\begin{array}{c}.473 \\
(5.54)^{* *}\end{array}$ \\
\hline Ln_energy & $\begin{array}{c}.742 \\
(8.96)^{* *}\end{array}$ & $\begin{array}{c}0.619 \\
(8.05)^{* *}\end{array}$ & $\begin{array}{c}0.352 \\
(4.15)^{* * *}\end{array}$ & $\begin{array}{c}0.347 \\
(4.39)^{* *}\end{array}$ & $\begin{array}{c}.596 \\
(7.03)^{* *}\end{array}$ & $\begin{array}{c}.467 \\
(5.65)^{* *}\end{array}$ \\
\hline Constant & $\begin{array}{l}7.794 \\
(4.18)^{* *}\end{array}$ & $\begin{array}{l}1.370 \\
(1.71)^{+}\end{array}$ & $\begin{array}{c}-0.174 \\
(1.02) \\
\end{array}$ & $\begin{array}{c}-0.074 \\
(0.33) \\
\end{array}$ & $\begin{array}{c}7.722 \\
(6.46)^{* *}\end{array}$ & $\begin{array}{l}-.508 \\
(0.60) \\
\end{array}$ \\
\hline$N$ & 806 & 806 & 806 & 806 & 806 & 806 \\
\hline Trend & Included & $\begin{array}{r}\text { Not } \\
\text { Included }\end{array}$ & Included & $\begin{array}{r}\text { Not } \\
\text { Included }\end{array}$ & Included & $\begin{array}{r}\text { Not } \\
\text { Included }\end{array}$ \\
\hline $\begin{array}{l}\text { Constant Returns to } \\
\text { Scale ( } p \text {-value) }\end{array}$ & 0.78 & 0.00 & 0.653 & 0.293 & 0.283 & 0.630 \\
\hline $\begin{array}{l}\text { Cross Sectional } \\
\text { Dependency ( } p \text {-value) }\end{array}$ & 0.00 & 0.00 & 0.00 & 0.007 & 0.466 & 0.074 \\
\hline Order of Integration & $\mathrm{I}(0)$ & $\mathrm{I}(0)$ & $\mathrm{I}(1) \sim \mathrm{I}(0)$ & $\mathrm{I}(1) \sim \mathrm{I}(0)$ & $\mathrm{I}(0)$ & $\mathrm{I}(0)$ \\
\hline
\end{tabular}


The labor, capital and energy coefficients of mean group model and common correlated mean group model, which doesn't include trend, were significant. Besides, the residuals of both models were stationary. But the residuals of the model, for which mean group estimator was used, were cross sectional dependent. Even though the model estimated with common correlated mean group estimator produced the residuals that were cross sectional dependent at the $10 \%$ significance level. It is possible to accept the empty hypothesis which means cross sectional independency, at the $5 \%$ significance level.

When the production function is estimated with heterogeneous models with trend, the capital stock becomes insignificant. Resulting as insignificant is a usually seen situation in literature. In addition, energy input can be considered as supplementary of the capital as well. When the residuals of the models including trend examined, it is seen that common correlated mean group estimator model doesn't contain cross sectional dependency. In addition, the model produced stationary residuals.

The energy variable resulted as insignificant in both models, which are estimated with cross section demeaned mean group estimator with or without trend. Moreover, when their residuals are examined, it is hard to decide exactly if the residuals are stationary, and it is revealed that the residuals of both models were cross sectional dependent. Therefore, it is not possible to use the model, estimated with this estimator.

After this stage, a choice between these two models including cross sectional independency is made and it is decided to move to next stage by using the residuals of common correlated mean group estimator, which doesn't include trend and in which, the capital stock is economically significant. In addition to this, the chi-square value generated by Wald test of the model, not including trend was higher than the one, including trend, reveals that the model, not including trend is suitable for use in the next stage.

In the next stage, the regression analysis was realized with respect to that how the productivity values which are determined by the production function, estimated by using common correlated mean group estimator, not including trend; were affected from regulation impact indicators. The results of this analysis are given in Table 6.

Table: 6

\section{Second Stage Estimation Results}

\begin{tabular}{lcc}
\hline & TFP & TFP \\
\hline$\Delta \ln \_$regulationimpact & -.0241597 & \\
Ln_regulationimpact & $(-3,45)^{* *}$ & -.0000985 \\
& & $(-1,58)$ \\
Constant & -.0011137 & -.0008945 \\
& $(-3,92)^{* *}$ & $(-1,59)$ \\
\hline$+p<0.1 ; * p<0.05 ; * * p<0.01$ & &
\end{tabular}


When the Table 6 examined, it is possible to say that regulation impact factor is insignificant logarithmically on the level ${ }^{2}$. Besides; the Chi-square values that were obtained as a result of the Wald test refused the model. When the growth rate of the regulation impact factor was analyzed, it is seen that it was significant at $1 \%$ level. In both cases, the direction of regulation impact is negative. As a result of using common correlated mean group estimator, which has used more flexible structure than other models did and allowed for heterogeneous effects, even though its significance level could decrease since it took into account the spillover effects as well, such a problem didn't exist after this model have been used.

Expressing the result of the estimation more clearly, how much the rate of growth of anti competitive regulations in the energy market increases, the more total factor productivity of the economy decreases. Since the growth rate was included in the model, this result implied that the change in the market would be more significant with the effect of expectations. In this regard, it is possible to conclude that the anti competitive regulations in energy markets have caused the total factor productivity of the economy to decrease.

\section{Conclusion}

This study examines how the regulations in the energy market affect the economy. For this purpose, the regulatory impact indicator which is created with the input-output tables and shows the impact of the energy market regulations on the entire market. When the present studies are examined, there has been no similar study encountered using regulation impact indicators in the energy market. Therefore, this study is expected to contribute to the existing literature.

It is considered in the study that working particularly with an accurate estimator could be influential on the results to accurately predict the production function. Thus, in order to find a response to the question intended in the study, the recent literature has been benefited from to find the correct estimator and new methods are also used considering cross-sectional dependency. It is interesting for future studies to see how the effects of defining different production function would be.

The regulatory impact indication that is an OECD calculation is used in the analysis. The main advantage of using this indicator is its direct relationship with existing policies. In this regard, it is expected that the analysis results will shed light on the energy market regulations to be made in the future. 
Selçuk, I.Ş. \& A.M. Köktaş (2016), "Energy Market Regulations and Productivity: An Examination on OECD Countries between the Years of 1975-2007", Sosyoekonomi, Vol. 24(27), 243-261.

As a result of all the analyses, the estimates were found to be biased determination of the results, if the horizontal cross-sectional dependence is not taken into account. Besides, when the horizontal cross-sectional dependence is not taken into account, the regulatory impact indicators affect the total factor productivity at approximately $3.8 \%$; and when the dependencies are taken into consideration this rates falls to approximately $2.4 \%$.

Therefore, another conclusion of the work is the necessity to consider that the criteria including only the spread of regulatory impact in the analyses, and there are also other impacts that cannot be observed. Otherwise, the obtained results may be biased.

When the results derived from the empirical study made with the 1975 to 2007 data of 28 OECD countries are considered, in accordance with the expectation, the anticompetitive regulations in the energy market have a negative impact on the total factor productivity which is the unexplained part of the economy by the economic factor inputs. This shows that the result might have a negative comeback to the economy when there is an anti-competitive regulation at the phase of forming energy market regulatory policies. The fact that the growth rate is significant, not the regulatory impact indication indicates that the impact of the expectations and the change in the market gives rise to more significant results. These results are important for the international capital movements and investments. Therefore, it is necessary to carefully examine the reflection of this result by policy makers.

\section{References}

Arnold, J. \& G. Nicoletti \& S. Scarpetta (2008), "Regulation, Allocative Efficiency and Productivity in OECD Countries: Industry and Firm-Level Evidence", OECD Economics Department Working Papers, No. 616, OECD Publishing. doi:10.1787/241447806226.

Arnold, J. \& G. Nicoletti \& S. Scarpetta (2011), "Does Anti-Competitive Regulation Matter for Productivity? Evidence from European Firms", IZA Discussion Paper, No. 5511.

Braila, C. \& G. Rayp \& S. Sanyal (2010), “Competition and Regulation, Belgium, 1997 to 2004”, Working Papers 1003, Federal Planning Bureau, Belgium.

Chang, Kuo-Ping (1994), "Capital-Energy Substitution and the Multi-Level CES Production Function", Energy Economics, 16, 22- 26.

Conway, P. \& G.D. de Rosa \& G. Nicoletti \& F. Steiner (2006), "Product Market Regulation and Convergence", OECD Economic Studies, No. 43, 2006/2, OECD, Paris.

De Serres, A. \& S. Kobayakawa \& T. Sløk \& V. Laura (2006), "Regulation of Financial Systems and Economic Growth", OECD Working Paper, No. 506.

Eberhardt, M. \& C. Helmers \& H. Strauss (2013), "Do Spillovers Matter When Estimating Private Returns to R\&D?", Review of Economics and Statistics, Vol. 95, 436-448.

Feenstra, R., Inklaar, R., \& Timmer, M. (2013). The Next Generation of the Penn World Table. Groningen Growth and Development Center, University of Groningen.

Grepperud, S. \& J. Rasmussen (2004), “A General Equilibrium Assessment of Rebound Effects”, Energy Economics, 26, 261-282. 
Selçuk, I.Ş. \& A.M. Köktaş (2016), "Energy Market Regulations and Productivity: An Examination on OECD Countries between the Years of 1975-2007", Sosyoekonomi, Vol. 24(27), 243-261.

Griliches, Z. (1979), "Issues in Assessing the Contribution of Research and Development to Productivity Growth", The Bell Journal of Economics, Vol.10, No:1, 92-116.

Kümmel, R. \& W. Strassl \& A. Gossner \& W. Eichhorn (1985), "Technical Progress and Energy Dependent Production Functions", Zeitschrift Für Nationalökonomie / Journal of Economics, 45(3), 285-311.

Kümmel, R. (2007), "The Productive Power of Energy and its Taxation”, 4th European Congress Economics and Management of Energy in Industry, Porto, Portugal, 27-30, November.

Lecca, P. \& K. Swales \& K. Turner (2011), “An Investigation of Issues Relating to Where Energy Should Enter The Production Function", Economic Modelling, Elsevier, 28(6), 28322841 .

Lindenberger, D. \& R. Kümmel (2002), "Energy-Dependent Production Functions and the Optimization Model 'PRISE' of Price-Induced Sectoral Evolution", International Journal of Applied Thermodynamics, 5(3), 101-107.

Lindenberger, D. (2003), "Service Production Functions", EWI Working Paper, No. 03.02, Institute of Energy Economics, University of Cologne (EWI).

Maddala, G., \& S. Wu (1999), "A Comparative Study of Unit Root Tests With Panel Data and A New Simple Test”, Oxford Bulletin of Economics and Statistics, Special Issue.

Pesaran, M.H. (2004), "General Diagnostic Tests for Cross Section Dependence in Panels", Cambridge Working Papers in Economics, No.0435, University of Cambridge.

Pesaran, M.H. (2007), "A simple panel unit root test in the presence of cross-section dependence", Journal of Applied Econometrics, 22(2), 265-312.

Pollitt, M.G. (2012), "The Role of Policy in Energy Transitions: Lessons from the Energy Liberalisation Era", Energy Policy, doi:10.106/j.enpol.2012.03.04.

Sorrell, S. (2008), "Energy-Capital Substitution and the Rebound Effect", Paper for the 7th BIEE Academic Conference: The New Energy Challenge: Security and Sustainability, St. John's College, Oxford, 24-25th September 2008.

Tintner, G. \& E. Deutsch \& R. Rieder (1974), “A Production Function for Austria Emphasizing Energy”, De Economist, 125(1), 75-94.

Thompson, H. (2006), “The Applied Theory of Energy Substitution in Production”, Energy Economics, Elsevier, July, 28(4), 410-425.

Van der Werf, E. (2008), "Production Functions for Climate Policy Modeling: An Empirical Analysis", Energy Economics, 30, 2964-2979.

The World Bank, World Development Indicators (2014), Energy Use (kg of oil equivalent), Retrieved from <http://data.worldbank.org/indicator/EG.USE.PCAP.KG.OE>.

Zenginobuz, Ü. (2000), “Elektrik Sektöründe Özelleştirme, Rekabet ve Regülasyon (Privatization, Competition, and Regulation in Electricity Supply Industry)", Rekabet Kurumu Perşembe Konferansları, 101-147, Ankara, 2000. 


\section{TECHNICAL APPENDIX}

\section{TA-1: Time-Series Properties}

Panel A: Levels

Constant

$\begin{array}{ll}\text { Lags } & \text { InYit } \\ 0 & 43.365(.891)\end{array}$

$9.523(1.00)$

$11.952(1.00)$

Constant

Lags $\ln Y$ it

$\begin{array}{ll}0 & 0.063(.525) \\ 1 & 3.300(1.00)\end{array}$

$3.300(1.00)$

Panel B: First Difference

$$
\begin{array}{ll}
\text { Lags } & \ln \text { Yit } \\
0 & 347.629(.00) \\
1 & 258.319(.00)
\end{array}
$$

Constant

Lags $\ln \mathrm{Yit}$

$\begin{array}{ll}0 & -9.313(.00) \\ 1 & -5.546(.00)\end{array}$

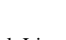

$56.822(.444)$

$53.126(.584)$
$15.581(1.00)$

$\operatorname{lnLit}$

InLit $0.785(.784)$

$1.165(.878)$

$5.859(1.00)$

\section{Constant}

$\operatorname{lnLit}$

$246.385(.00)$

$214.521(.00)$

$\operatorname{lnLi}$

$-9.645(.00)$

$3.651(.00)$
Maddala and Wu (1999) Fisher Test

$\begin{array}{ll}\ln K i t & \text { LnEit } \\ 507.592(.00) & 107.282(.00) \\ 103.476(.00) & 35.325(.986) \\ 34.826(.988) & 37.770(.971)\end{array}$
Constant and $\mathrm{T}$

$\begin{array}{lll}\text { LnRIit } & \text { Lags } & \ln Y \text { it } \\ 1.661(.00) & 0 & 92.326(.002)\end{array}$

$\begin{array}{lll}1.661(.00) & 0 & 92.326(.002) \\ 5.441(1.00) & 1 & 97.050(.001)\end{array}$

$111.540(.00) \quad 2 \quad 148.567(.00)$ Pesaran (2007) CIPS Test

$\operatorname{lnKit}$
$-6.798(.00)$
$0.157(.562)$
$4.055(1.00)$

LnEit
$-3.315(.00)$
$-0.975(.165)$
$2.463(.993)$

Constant and Trend

LnRIit Lags $\ln \mathrm{Yit}$

$\begin{array}{lll}1.185(.882) & 0 & -0.019(.492)\end{array}$

$0.143(.557) \quad 1 \quad 0.931(.824)$

$3.916(1.00) \quad 2 \quad 4.207(1.00)$

$\operatorname{lnLi}$

24.911 (1.00)

$79.244(.022)$

$42.264(.913)$

$\operatorname{lnKi}$

$191.551(.00)$

$126.683(.00)$

$103.964(.00)$

LnEi

$113.830(.00)$

$94.472(.001)$

$81.088(.016)$

LnRI

$0.206(1.00)$

(2.933 (1.00)

$1.720(.957)$

$1.854(.968)$

$\operatorname{lnKit}$

$-1.129(.13)$

$0.428(.666)$

LnEit

$-0.991(.161)$

$0.784(.783)$

$3.426(1.00)$

LnRIit

$1.248(.894)$

$-0.886(.188)$

$3.950(1.00)$

Maddala and Wu (1999) Fisher Test

InKit

$192.411(.00)$

LnEit
$705.832(.00)$

Constant and Trend

$\begin{array}{lll}\text { LnRIit } & \text { Lags } & \ln Y \text { it } \\ 338.651(.00) & 0 & 252.079(.00)\end{array}$

Pesaran (2007) CIPS Test
Pest

$\operatorname{lnLit}$

$225.965(.00)$

$164.530(.00)$

$86.775(.005)$

LnEit

Constant and Trend

$\operatorname{lnKit}$

LnEit

$-18.052(.00)$

LnRIit Lags $\ln Y$ it

$-12.957(.00)$
$-9.332(.00)$

$-7.088(.00)$

$\operatorname{lnLit}$

$-8.054(.00)$

$\ln \mathrm{Kit}$

$-1.941(.026)$

$2.988(.999)$

$579.528(.00)$

$257.421(.00)$

LnRIit

$404.969(.00)$

$282.951(.00)$

LnEit

$-15.851(.00)$

LnRIit

$-11.550(.00)$ $\begin{array}{lll}338.651(.00) & 0 & 252.079(.00) \\ 154.339(.00) & 1 & 181.803(.00)\end{array}$

$-0.834(.202)$

\section{TA-2: Cross-Section Correlation}

$\begin{array}{llll}\text { Levels } & \text { CD } & \text { p-val. } & \text { Avg } \rho \\ \quad \text { Ln Y } & 90.71 & 0.000 & 0.948 \\ \text { LnL }_{\text {it }} & 42.04 & 0.000 & 0.387 \\ \text { LnK }_{\text {it }} & 93.99 & 0.000 & 0.982 \\ \quad \text { Ln E } & 49.71 & 0.000 & 0.486 \\ \text { LnRI }_{\text {it }} & 85.09 & 0.000 & 0.890\end{array}$

First Difference
$\Delta \mathrm{Ln} \mathrm{Y}_{\text {it }}$
$\Delta \mathrm{LnL}_{\mathrm{it}}$
$\Delta \mathrm{LnK}_{\mathrm{it}}$
$\Delta \mathrm{Ln} \mathrm{E}_{\mathrm{it}}$
$\Delta \mathrm{LnRI}_{\mathrm{i}}$

CD

23.95

20.21

18.88

15.54

19.39 p-val.

0.000

0.000

0.000

0.000

0.000

Avg
0.262
0.212
0.190
0.135
0.191

Avg $|\rho|$

0.349

0.299

0.411

0.275

0.269 